University of Nebraska - Lincoln

DigitalCommons@University of Nebraska - Lincoln

Faculty Papers and Publications in Animal

Science

Animal Science Department

January 1967

\title{
EFFECT OF PLANE OF NUTRITION, SEX AND BODYWEIGHT ON THE CHEMICAL COMPOSITION OF YORKSHIRE PIGS
}

\author{
G. M. Babatunde \\ Cornell University \\ W. G. Pond \\ Cornell University \\ L. Dale Van Vleck \\ University of Nebraska-Lincoln, dvan-vleck1@unl.edu \\ G. H. Kroening \\ Cornell University \\ J. T. Reid \\ Cornell University
}

Follow this and additional works at: https://digitalcommons.unl.edu/animalscifacpub

Part of the Animal Sciences Commons

Babatunde, G. M.; Pond, W. G.; Van Vleck, L. Dale; Kroening, G. H.; and Reid, J. T., "EFFECT OF PLANE OF NUTRITION, SEX AND BODYWEIGHT ON THE CHEMICAL COMPOSITION OF YORKSHIRE PIGS" (1967).

Faculty Papers and Publications in Animal Science. 324.

https://digitalcommons.unl.edu/animalscifacpub/324

This Article is brought to you for free and open access by the Animal Science Department at DigitalCommons@University of Nebraska - Lincoln. It has been accepted for inclusion in Faculty Papers and Publications in Animal Science by an authorized administrator of DigitalCommons@University of Nebraska - Lincoln. 
Babatunde, G. M., W. G. Pond, L. D. Van Vleck, G. H. Kroening, and J. T.Reid. 1967. Effect of plane of nutrition, sex, and body weight on the chemical composition of Yorkshire pigs. Journal of Animal Science 26:718-726.

Abstract: An experiment was carried out involving the full-vs. limited-feeding of 9 pairs of gilts and 6 of barrows from a population of closely related Yorkshire pigs from approximately $45 \mathrm{~kg}$. live weight up to each of three predetermined slaughter weight groups (79, 90 and $102 \mathrm{~kg}$.). The objective was to determine the effects of level of feed intake, sex and weight on the chemical composition of the empty body, edible carcass and inedible parts (offal) and the fatty acid composition of the mid-back fat. As the slaughter weight increased, the percentages of empty body, carcass and offal protein and water decreased significantly, while the percentage of extractable fat increased significantly. These changes were most noticeable between the lightest (79 kg.) vs. the two heavy groups (90 and $102 \mathrm{~kg}$.), but the two heavy groups had similar chemical composition. In absolute quantities, the protein, fat, water and ash increased as the slaughter weight increased. Since the chemical composition of the offal followed the same trends as observed for the carcass or the empty body and were fairly close in the three categories, it would appear that a reasonably high impression of the chemical composition of either the empty body or the carcass could be gained by analyzing the inedible parts (head, empty gastrointestinal tract and all other internal organs) and saving the edible carcass. There were no significant weight group differences in the fatty acid composition of the back fat, but the lightest pigs had slightly higher proportions of the unsaturated fatty acids and less of the saturated ones than the heavy groups. The restricted-fed pigs in all cases had higher percentages of protein, ash and water, and lower fat than the full-fed pigs; these differences being significant in most of the comparisons, except for the ash content that showed no significant differences in the carcass, offal or empty body. The absolute quantities of the protein, fat, ash and water for full-vs. limited-fed pigs followed the same trends as the percentages above. Feed restriction had the effect of increasing significantly the percentages of most of the unsaturated fatty acids and decreasing the percentages of the saturated fatty acids.

Copyright $\odot 1967$ American Society of Animal Science. Used by permission. 


\title{
EFFECT OF PLANE OF NUTRITION, SEX AND BODYWEIGHT ON THE CHEMICAL COMPOSITION OF YORKSHIRE PIGS
}

\author{
G. M. Babatunde, W. G. Pond, L. D. VanVleck, \\ G. H. Kroening and J. T. Reid \\ Cornell University, Ithaca, New York ${ }^{1}$
}

\begin{abstract}
CHANGES in the chemical composition of $G$ the pig with increasing age and weight have been studied by Mitchell and Hamilton (1929), Scott (1930), Callow (1935), Moulton et al. (1922) and Spray and Widdowson (1951). Likewise, the chemical analyses of all or some parts of animals or carcasses have been used to validate various indirect methods of estimating body composition (Morales et al., 1945; Messinger and Steele, 1949; Kraybill et al., 1953; Doornenbal, 1961; Osinska, 1962; and Gnaedinger et al., 1963). However, the chemical composition of fullvs. restricted-fed pigs started and slaughtered at identical live weights has not been compared. This experiment was designed to investigate the chemical composition of the empty body, edible carcass and all other body parts (later referred to as "offal") and the fatty acid constituents of mid-back fat associated with differences in bodyweight, sex and feed intake of growing pigs.

Mean values for bodyweight gain, feed data and for some of the carcass measurements as well as statistical relationships among some of the physical and chemical parameters in this experiment were reported previously (Babatunde et al., 1966).
\end{abstract}

\section{Experimental}

Thirty closely-related Yorkshire barrows and gilts (18 gilts and 12 barrows) weighing between 20 and $27 \mathrm{~kg}$. were housed in individual pens and fed ad libitum on $19.8 \%$ protein in a diet adequate in all known nutrients until they reached $45.5 \pm 2.3 \mathrm{~kg}$. live weight. The percentage composition of the diet was: ground yellow corn, 69.0; soybean meal, 27.25 ; dicalcium phosphate, 2.0 ; trace mineralized salt, 0.5 ; ground limestone, 0.5 ; vitamin premix, 0.5 ; antibiotic supplement, 0.25 . This high level of protein was used to ensure adequate protein intake even at the level of

1 The authors gratefully acknowledge G. H. Wellington and J. R. Stouffer for physical carcass measurements, Harry Dickson and Joe Powell for help with the slaughtering and grinding of the carcasses and Mrs. Phyllis Chapman and Earl Walker, Jr. for help with the chemical analyses. restriction imposed. At $45,5 \pm 2.3 \mathrm{~kg}$. live weight, they were paired on the bases of sex and weight. One member of each pair was randomly assigned to full-feed intake, while the other was fed $1.82 \mathrm{~kg}$. per day. Bodyweight of each pig and feed intake of full-fed pigs were recorded weekly.

Three slaughter weight groups were selected $(79,90$ and $102 \mathrm{~kg}$.) within each group; two predetermined pairs of barrows and three of gilts were slaughtered with a preslaughter shrinkage allowance of 3 to 4 kilograms. Feed, but not water, was withdrawn approximately $16 \mathrm{hr}$. prior to slaughter. Bodyweight of each pig was recorded just before slaughter. Blood at sticking was collected and weighed. The dehaired pigs were dressed in the conventional way; the hair being discarded in all cases. The fresh weights of all the internal organs, together with the heads and the empty gastrointestinal tracts, were recorded and all were combined. The weighed, dressed carcasses were chilled for $24 \mathrm{hr}$. in a refrigerated room maintained at $4^{\circ} \mathrm{C}$. Conventional carcass measurements were taken on the right halves of the carefully split carcasses after chilling, while the left halves were used for chemical determinations.

For each pig, the offal and carcass were separately ground seven times. ${ }^{2}$ Final sampling of the ground materials took place during the seventh grinding into three aluminum pans of dimensions $34 \times 20 \times 5.6 \mathrm{~cm}$. Each sample of about 1.5 to $2 \mathrm{~kg}$. per pan was evenly spread out in the pan, covered with thin aluminum foil, weighed and then dried in a freeze drier ${ }^{3}$ to constant weight ( 4 to 5 days). The percentage of moisture was computed from the weights of the samples before and after drying. Fine grinding of the dried samples for chemical analysis was done with a Wilev Mill model No. 2, using a $2 \mathrm{~mm}$. sieve. The freeze dried triplicate samples were

225 H.P., 220 to 440 volts electric meat grinder. the Fairbanks Morse motor type QZFK, rotating at 1460 RPM with a motor reducer at the rate of 15.5 RPM, giving a ratio of 11.36 .

${ }^{3}$ Desivac, F. J. Stokes Corporation, Philadelphia 20 , 
re-sampled into a single bulk and mixed with dry ice in the ratio of $1: 3$ (sample:dry ice), allowed to stand covered up for about $5 \mathrm{~min}$. to make it easier to grind the fatty materials, and then fed gradually into the grinder. The finely-ground mixture of ice and sample was left exposed overnight to allow the dry ice to disappear, after which the samples were bottled until analyzed as follows:

Total nitrogen was determined by the macro-KjeldahI method of A.O.A.C. (1955). Duplicate sample sizes of 1.0 to $1.5 \mathrm{gm}$. were used. The total $\mathrm{N} \times 6.25$ gave the crude protein content.

The residual moisture in the samples (absorbed when the ground samples were being exposed to the atmosphere to allow the dry ice to disappear before bottling) was determined on samples 5 to $6 \mathrm{gm}$. weighed into aluminum extraction thimbles which had been previously oven-dried, cooled and freeze-dried to constant weight. The dried samples were used for fat and total ash determinations.

For fat determination the dried samples from above were plugged with glass wool and placed in large Soxhlet Extractors for conventional ether extraction.

Ash was determined by keeping the etherextracted samples in an electric furnace maintained at $550^{\circ} \mathrm{C}$. for 3 days.

The percentages of all the proximate chemical components were calculated first on a per gram of dry matter basis and then for the total dry matter of the offal and carcass; and, finally, computed for the whole empty body of the animals.

Gross energy was determined on samples of about $1 \mathrm{gm}$. which were pelleted and used in the Parr's Adiabatic Oxygen Bomb calorimeter.

Fatty acids in the backfat was measured in $10 \mathrm{gm}$. portions of the mid-back fat samples which were mixed and heated at $110^{\circ} \mathrm{C}$. for $2 \mathrm{hr}$. to melt. Methylation of the melted samples was done according to the method of DeMann (1964). They were heated for $4 \mathrm{hr}$. in anhydrous reagent grade methanol and sample sizes of 5 to $10 \mu \mathrm{l}$. of the methanol esters used in the gas chromatographic analysis, using Beckman G. C., Model 2A. Helium gas flow rate was 40 to $60 \mathrm{ml}$. per minute. The stainless steel columns were $2 \mathrm{~m}$. long and the substrate was $15 \%$ ethylene glycol succinate on 60 to 80 mesh chromasorb WDCMS.

The data were statistically analyzed according to the unweighted squares of means method with three weight groups, to treatments and two sexes giving a $3 \times 2 \times 2$ factorial design. The comparisons were made between two groups at a time, two treatments and two sexes, thus giving one degree of freedom for group, treatment, or sex and 18 for the error mean square. The analysis of variance is as follows:

\begin{tabular}{lr} 
Source of variance & d.f. \\
\cline { 2 - 2 } Treatment (T) & 1 \\
Sex $(\mathrm{S})$ & 1 \\
Weight $(\mathrm{W})$ & 2 \\
$\mathrm{~W}_{1}$ vs. $\mathrm{W}_{2}^{*}$ & 1 \\
$\mathrm{~W}_{1}$ vs. $\mathrm{W}_{3}^{*}$ & 1 \\
$\mathrm{~W}_{2}$ vs. $\mathrm{W}_{3}^{*}$ & 1 \\
TS & 1 \\
TW & 2 \\
SW & 2 \\
TSW & 2 \\
Residual & 18 \\
nn-orthogonal comparisons. &
\end{tabular}

Statements of statistical significance refer to the 0.05 level of probability. The correlationregression analyses were run with sex, treatment and weight groups disregarded.

\section{Results and Discussions}

Chemical Composition of the Empty Body, Carcass and Offal. Tables 1,2 and 3 give the means and the " $F$ " values for the three weight groups and the two dietary treatments related to composition of the empty body, carcass and offal, respectively. Pigs slaughtered at the lightest weight $(79 \mathrm{~kg}$.) had significantly higher empty body protein and water, and significantly lower fat and gross energy than either of the two heavy groups ( 90 or $102 \mathrm{~kg}$.) The ash content showed no significant difference among the groups. However, the differences in the empty body proximate constituents of the $90 v s .102 \mathrm{~kg}$. were not significant and, in most cases, the means were almost identical.

Restricting feed intake to $1.82 \mathrm{~kg}$. per head per day significantly increased the empty body protein and reduced the fat; although the means for ash and water contents were also greater in the restricted group, the observed differences were not statistically significant.

The chemical composition of the carcass and offal largely followed the same trends as observed for the empty body. The only deviation observed between the carcass and empty body chemical composition was in the 
water content of the carcass in which the limited-fed pigs had significantly higher water content than the full-fed pigs. In the chemical composition of the offal, none of the differences observed in the protein percentages among weight groups was significant nor were the treatment differences in fat, ash and water. Mean protein was highest for the lightest group and diminished gradually as the slaughter weight increased. Also, the full-fed pigs had slightly higher extractable fat in the offal than their limited-fed counterparts. All other comparisons gave results similar to those for empty body or carcass composition.

Of special importance is the large difference observed between the proximate constituents of the lightest group compared with the two heavier groups. These differences, which tended to be highly significant when comparing the lightest vs. heaviest pigs, were not evident when the two heaviest groups were compared (90 vs. $102 \mathrm{~kg}$.). In fact, the chemical composition of the empty body, the carcass and the offal to a large extent, are almost identical for these two heavy groups. Although these percentages were not based on fat-free body, they fit well with Moulton's (1923) concept of chemical maturity. In the light of the evidence obtained that the proxi- mate chemical constituents were remarkably different between the $79 \mathrm{vs} .90 \mathrm{~kg}$. groups but approached constant figures with the $90 \mathrm{vs}$. $102 \mathrm{~kg}$. groups, it would appear that, at about $90 \mathrm{~kg}$. live weight, the pig is already chemically mature, and further changes are effected only by the imposition of extremely rigorous treatments. On the other hand, these figures were not strictly constant but varied slightly. Reid et al. (1955) in their investigation with cattle observed this same phenomenon and submitted that these chemical constituents are not absolutely constant but do vary within narrow limits.

The absolute weights of empty body protein and fat have been regressed on the empty bodyweights for the three groups (see figures 1 and 2) and the regression equations also shown for these relationships. These graphs clearly show that the absolute quantities of empty body protein and fat increased with increase in slaughter weight, unlike the same variables expressed as percentages of the empty bodyweight (table 1) which showed significant differences only between the 79 and $102 \mathrm{~kg}$. groups, but not between the 90 and $102 \mathrm{~kg}$. groups. The distribution of the points along the regression line shows clearly the differences in the absolute quantities of empty

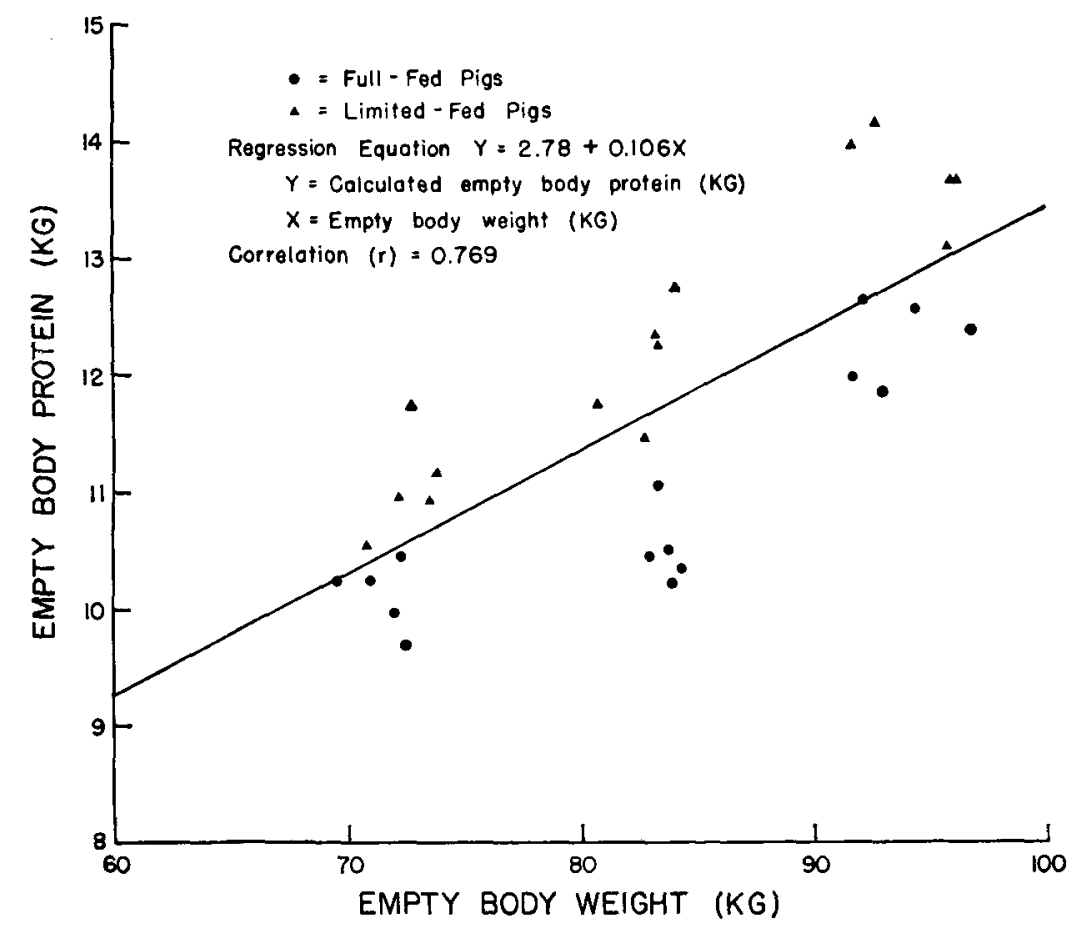

Figure 1. Effect of empty bodyweight (total weight minus gastrointestinal contents) on weight of empty body protein in limited- and full-fed pigs. 


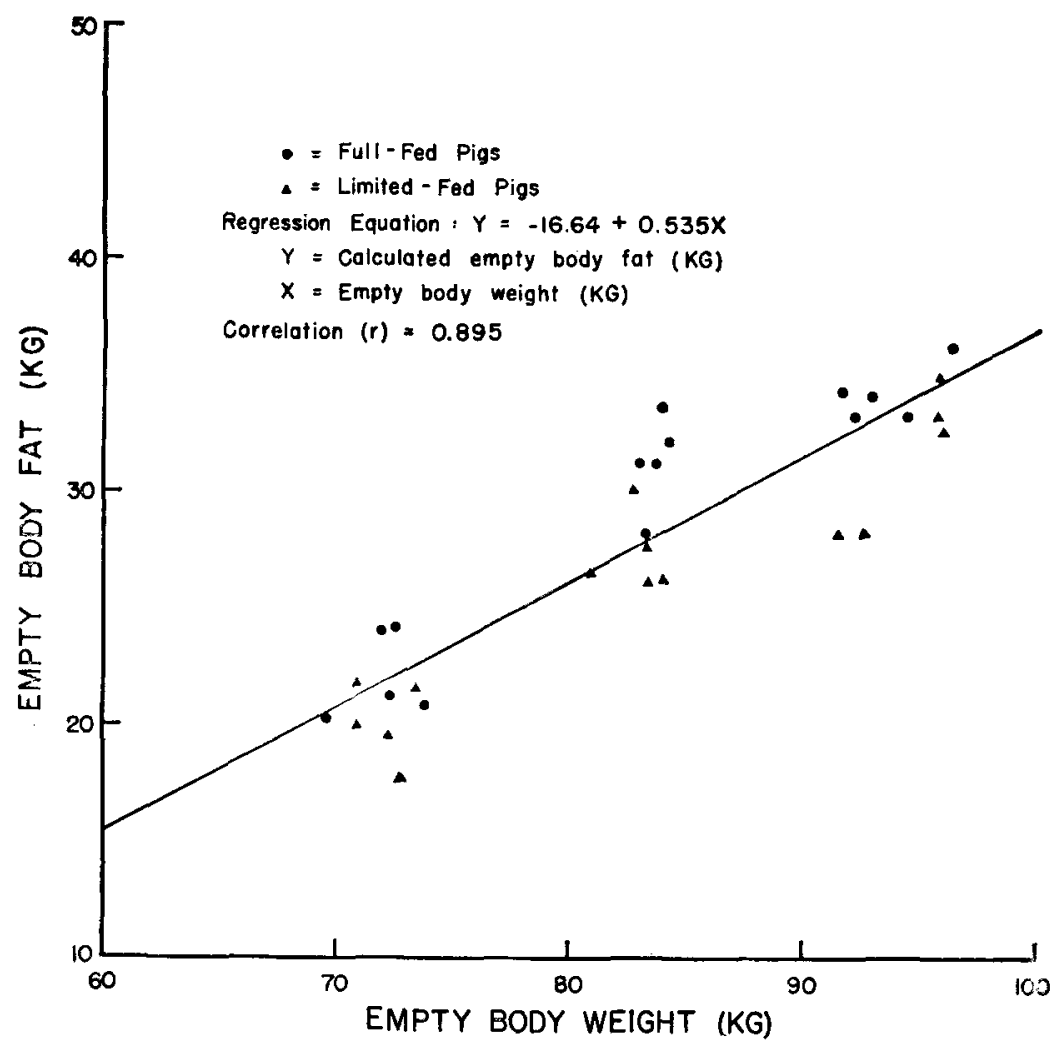

Figure 2. Effect of empty bodyweight (total weight minus gastrointestinal contents) on weight of empty body fat in limited- and full-fed pigs.

body protein and fat for the full-fed pigs from those of the limited-fed pair mates for the three groups. These facts suggest that, although weight influenced the chemical composition of these pigs, dietary treatment was effective in bringing about a different distribution of points on either side of the regression line for both protein and fat within each weight group.

Except for the degrees of significance attained by the differences, the chemical composition of the offal followed the same trends observed for the carcass and the empty body. This indicates that one could have a reasonably good idea of the chemical composition of either the carcass or the empty body by analyzing the portions of the body which are composed of mostly the nonedible parts (the empty gastrointestinal tract, head and internal organs) and applying the regression equations shown below to predict any of the chemical components of the empty body.

$\mathrm{Kg}$. offal protein (Y) on kg. empty body protein $(\mathrm{X})(\mathrm{r}=.827) ; \mathrm{Y}=.754+5.696$ (X)
$\mathrm{Kg}$. offal fat on $\mathrm{kg}$. empty body fat ( $\mathrm{r}=$ $.928) ; \mathrm{Y}=6.059+5.501(\mathrm{X})$

$\mathrm{Kg}$. offal water on $\mathrm{kg}$. empty body water $(r=.712) ; Y=9.607+3.792(X)$

$\mathrm{Kg}$. offal total ash on kg. empty body total ash $(\mathrm{r}=.625) ; \mathrm{Y}=.995+2.770(\mathrm{X})$

Where $\mathrm{Y}$ represents the $\mathrm{kg}$. empty body protein, fat, water or total ash that are to be predicted from the known quantities of $\mathrm{kg}$. offal protein extractable fat, water or total ash (X). The magnitudes of the correlation coefficients between the pairs of variables are given by the values, " $r$ ".

Some other useful regression equations which could be used to predict carcass or offal proximate chemical components from known absolute weights of carcass and offal are shown below, together with the correlation coefficients, $r$, between the pairs.

Kg. carcass protein on carcass wt. (kg.): $\mathrm{r}=.779 ; \mathrm{Y}=2.15+.111(\mathrm{X})$

Kg. carcass fat on carcass wt. (kg.): $r=$ $.875 ; \mathrm{Y}=-12.012+.524(\mathrm{X})$

Kg. carcass water on carcass wt. (kg.): $\mathrm{r}=.834 ; \mathrm{Y}=10.301+.319(\mathrm{X})$ 


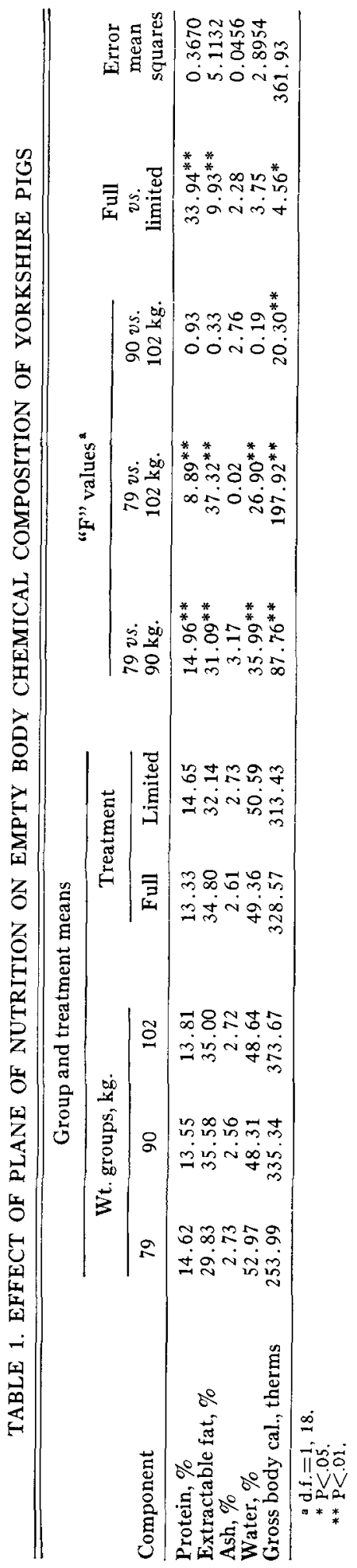

$\mathrm{Kg}$. offal protein on $\mathrm{kg}$. offal wt.: $\mathrm{r}=$ $.828 ; \mathrm{Y}=.495+.096(\mathrm{X})$

$\mathrm{Kg}$. offal fat on kg. offal wt.: $\mathrm{r}=.918$; $\mathrm{Y}=-3.921+.536(\mathrm{X})$

$\mathrm{Kg}$. offal water on kg. offal wt.: $\mathrm{r}=.917$; $\mathrm{Y}=2.835+.379(\mathrm{X})$

$\mathrm{Y}$ represents the carcass or offal proximate components to be predicted from known carcass or offal absolute weights $(\mathrm{X}), \mathrm{kg}$.

The proximate chemical components of the full- and limited-fed pigs followed the same trends in the empty body, carcass and offal, the full-fed pigs always having a higher percentage of fat but lower percentages of protein, ash and water than the limited-fed pigs. This would seem to justify the conclusion that in the pig there is no fat re-distribution through feed restriction, and that full- and limited-fed pigs slaughtered at the same live weight will not have identical chemical composition, a phenomenon that has been observed with the sheep (J. T. Reid, unpublished data). For, if there were fat re-distribution from the carcass to the internal organs, one would expect the offal of restricted-fed pigs to have significantly higher extractable fat than that of full-fed pigs. As the results showed (tables 1, 2 and 3 ), this was not so.

Effects on Fatty Acid Constituents of the Mid-back Fat. Table 4 gives the means and the $\mathrm{F}$ values for the weight groups and the treatments. Except for the 79 vs. $90 \mathrm{~kg}$. groups which gave a significant difference in oleic acid content alone, all other weight group comparisons in fatty acids showed no significant difference. The broad generalization to be made from these results is that the lightest pigs at slaughter had lower percentages of the saturated acids (palmitic and stearic) and higher percentages of unsaturated acids (oleic and linoleic). The figures for the $102 \mathrm{~kg}$. weight, however, did not entirely conform to this generalization, and the anomalous data for this group could have been caused by the fact that the level of restriction imposed had a much greater influence on this group and tended to soften the back fat. Apart from these slight deviations, however, it would appear that the lightest pigs have relatively more unsaturated and less saturated fatty acids than the heaviest groups and, consequently, as the pig ages and fattens, the proportion of saturated fatty acids increases while the unsaturated fatty acids decrease, accounting for the softer fat of younger pigs. This generalization largely agrees with McMeekan's view (1940) that after 8 weeks 

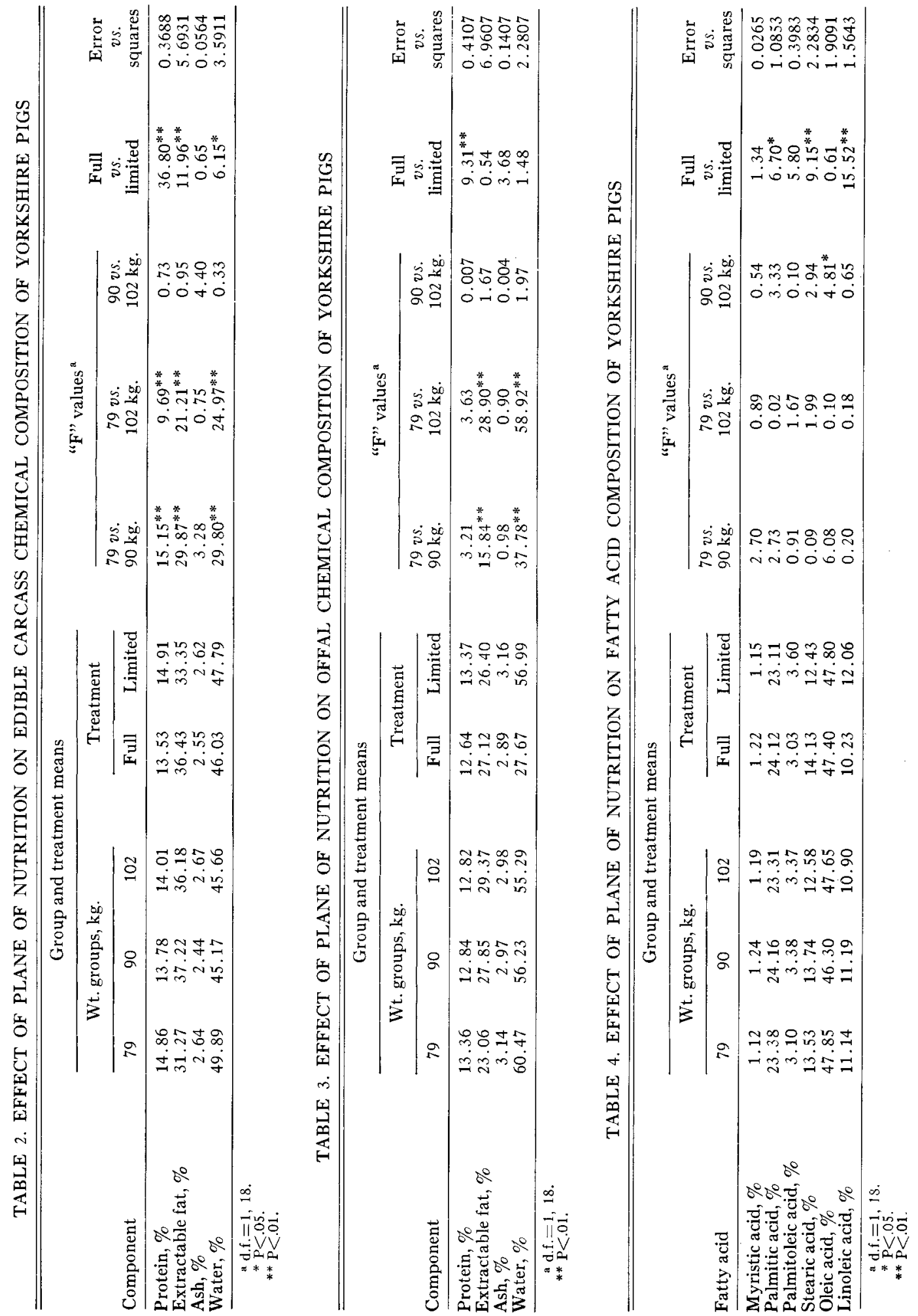
of age, the fat becomes more saturated and the iodine number drops as fattening progresses.

There were, however, remarkable treatment differences in the fatty acids. The full-fed pigs had significantly higher palmitic and stearic acids, and significantly lower palmitoleic and linoleic acids. Myristic and oleic acids showed no significant treatment differences, but the former was slightly higher and the latter slightly lower for full- than limited-fed pigs. These results conform to the findings of previous workers, most of whom had carried out only physical determinations, such as refractive index or specific gravity. Callow (1935) had reported that the rate of growth has an effect on the nature of fat deposited by the pig, claiming that the slow-grower usually has a slower rate of fat deposition and, therefore, does not need to synthesize fat from carbohydrate to the same extent as a rapidly growing, full-fed pig. He concluded that the fat produced by slow-growing pigs is, consequently, more likely to resemble the ingested fat of the food and be relatively unsaturated.
Similarly, McMeekan (1940) found that severe restriction in feed intake of pigs after $45 \mathrm{~kg}$. live weight caused increases of 4 and 3 units of iodine number for the inner and outer back fat of pigs, respectively, compared to the full-fed pigs. Hilditch et al. (1939) reported that on a restricted diet, the deposition of fat was not only slower but the fat produced was also softer, owing to small increases in the proportion of linoleic and oleic acids.

Sex Differences in Chemical Composition of Pigs. Table 5 gives the means, $F$ values and the mean squares of the proximate constituents of the two sex groups. With respect to protein percentages, the gilts had significantly higher carcass protein and not significantly higher empty body and offal protein than the barrows. With regard to extractable fat, the barrows had significantly higher empty body and carcass extractable fat, but not significantly higher offal fat than the gilts. The mean ash content was higher in all cases for gilts than for barrows, though the differences were not significant. Gilts also had signifi-

TABLE 5. SEX DIFFERENCES IN THE CHEMICAL COMPOSITION OF EMPTY BODY, CARCASS AND OFFAL OF YORKSHIRE BARROWS AND GILTS

\begin{tabular}{|c|c|c|c|c|}
\hline \multirow[b]{2}{*}{ Component } & \multicolumn{2}{|c|}{ Means } & \multirow[b]{2}{*}{ "F" values" } & \multirow{2}{*}{$\begin{array}{c}\text { Error } \\
\text { mean squares }\end{array}$} \\
\hline & Barrows & Gilts & & \\
\hline \multicolumn{5}{|l|}{ Empty body composition } \\
\hline Empty body wt., kg. & 83.16 & 83.03 & 0.05 & 2.7761 \\
\hline Protein, \% & 13.79 & 14.20 & 3.34 & 0.3670 \\
\hline Extractable fat, \% & 34.55 & 32.39 & $6.52^{*}$ & 5.1132 \\
\hline Ash, $\%$ & 2.60 & 2.74 & 2.77 & 0.0456 \\
\hline Water, \% & 49.14 & 50.81 & $6.86^{*}$ & 2.8954 \\
\hline Gross body calories, therms & 329.85 & 312.14 & 6.24 & 362 \\
\hline \multicolumn{5}{|l|}{ Carcass composition } \\
\hline Fresh carcass wt, kg. & 68.22 & 68.51 & 0.22 & 2.75 \\
\hline Protein, \% & 13.97 & 14.47 & $4.75 *$ & 0.3688 \\
\hline Extractable fat, \% & 36.11 & 33.66 & $7.60^{*}$ & 5.6931 \\
\hline Ash, $\%$ & 2.51 & 2.65 & 2.54 & 0.0564 \\
\hline Water, \% & 45.89 & 47.93 & $8.39 * *$ & 3.5911 \\
\hline \multicolumn{5}{|l|}{ Offal composition } \\
\hline Fresh offal wt., $\mathrm{kg}$. & 14.94 & 14.52 & 2.87 & 0.4461 \\
\hline Protein, $\%$ & 12.90 & 13.12 & 0.85 & 0.4107 \\
\hline Extractable fat, $\%$ & 27.34 & 26.18 & 1.39 & 6.9607 \\
\hline Ash, $\%$ & 2.93 & 3.12 & 1.87 & 0.1407 \\
\hline Water, \% & 56.77 & 57.90 & 4.03 & 2.2807 \\
\hline \multicolumn{5}{|l|}{ Fatty acid composition } \\
\hline Myristic acid, \% & 1.16 & 1.20 & 0.43 & 0.0265 \\
\hline Palmitic acid, \% & 23.45 & 23.78 & 0.69 & 1.0853 \\
\hline Palmitoleic acid, $\%$ & 3.19 & 3.44 & 1.18 & 0.3983 \\
\hline Stearic acid, \% & 13.50 & 13.06 & 0.61 & 2.2834 \\
\hline Oleic acid, $\%$ & 47.51 & 47.69 & 1.45 & 1.9091 \\
\hline Linoleic acid, \% & 10.83 & 11.45 & 1.75 & 1.5643 \\
\hline
\end{tabular}

a d.f. $=1,18$.

* $\mathrm{P}<.05$. 
cantly higher empty body water and carcass water, but not significantly higher offal water than the barrows. There were no significant sex differences in fatty acid constituents.

There is no direct evidence to cite in support of the above findings, but indirect evidence from physical determinations exist. For instance, Bennett and Coles (1946), Fredeen and Lambroughton (1956) and Wallace (1965), among many others, reported significantly higher proportions of lean and much reduced back fat thickness and other fat measures in gilts than barrows. Since lean cuts are associated with higher proportions of water and protein, while the fat cuts distinctly have higher extractable fat, it would seem that the gilts with higher lean and lower fat cuts should have higher protein and water, and lower extractable fat than the barrows.

\section{Summary}

An experiment was carried out involving the full- $v s$. limited-feeding of 9 pairs of gilts and 6 of barrows from a population of closely related Yorkshire pigs from approximately $45 \mathrm{~kg}$. live weight up to each of three predetermined slaughter weight groups $(79,90$ and $102 \mathrm{~kg}$.). The objective was to determine the effects of level of feed intake, sex and weight on the chemical composition of the empty body, edible carcass and inedible parts (offal) and the fatty acid composition of the mid-back fat.

As the slaughter weight increased, the percentages of empty body, carcass and offal protein and water decreased significantly, while the percentage of extractable fat increased significantly. These changes were most noticeable between the lightest (79 kg.) vs. the two heavy groups (90 and $102 \mathrm{~kg}$.), but the two heavy groups had similar chemical composition. In absolute quantities, the protein, fat, water and ash increased as the slaughter weight increased.

Since the chemical composition of the offal followed the same trends as observed for the carcass or the empty body and were fairly close in the three categories, it would appear that a reasonably high impression of the chemical composition of either the empty body or the carcass could be gained by analyzing the inedible parts (head, empty gastrointestinal tract and all other internal organs) and saving the edible carcass.

There were no significant weight group differences in the fatty acid composition of the back fat, but the lightest pigs had slightly higher proportions of the unsaturated fatty acids and less of the saturated ones than the heavy groups.

The restricted-fed pigs in all cases had higher percentages of protein, ash and water, and lower fat than the full-fed pigs; these differences being significant in most of the comparisons, except for the ash content that showed no significant differences in the carcass, offal or empty body. The absolute quantities of the protein, fat, ash and water for full- vs. limited-fed pigs followed the same trends as the percentages above.

Feed restriction had the effect of increasing significantly the percentages of most of the unsaturated fatty acids and decreasing the percentages of the saturated fatty acids.

\section{Literature Cited}

A.O.A.C. 1955. Official Methods of Analysis (8th ed.), Association of Official Agricultural Chemists. Washington, D. C.

Babatunde, G. M., W. G. Pond, L. D. Van Vleck, G. H. Kroening, J. T. Reid, J. R. Stouffer and G. H. Wellington. 1966. Relationships among some physical and chemical parameters of full-verus limited-fed Yorkshire pigs slaughtered at different live weights. J. Animal Sci. 25:526.

Bennett, J. A. and J. H. Coles. 1946. A comparative study of certain performance characteristics of Yorkshire barrows and gilts. Sci. Agr. 26:265.

Callow, E. H. 1935. Carcass quality of the pig in relation to growth and diet. Empire J. Exp. Agr. $3: 80$.

Doornenbal, H. 1961. The relationship between $\mathrm{Cr}^{51}$ determined red cell volume and the lean body mass in rats and pigs. Ph.D. Thesis. Cornell University, Ithaca, New York.

Fredeen, H. T. and D. B. Lambroughton. 1956. Evaluation of carcass quality of swine as influenced by the differential performance of barrows and gilts. Can. J. Agr. Sci. 36:435.

Gnaedinger, R. H., A. M. Pearson, E, P. Reineke and V. M. Hix. 1963. Body composition of market weight pigs. J. Animal Sci. 22:495.

Hilditch, J. P., C. H. Lee and W. H. Pedelty. 1939. The influence of low and high planes of nutrition on the composition and synthesis of fat in the pig. Biochem. J. 33:493.

Kraybill, H. F., E. R. Goode, R. S. B. Robertson and $\mathrm{H}$. S. Sloane. 1953. In vivo measurement of body fat and body water in swine. J. Appl. Physiol. 6:27.

DeMann, J. M. 1964. Determination of fatty acid composition of milk fat by column temperature gas liquid chromatography. J. Dairy Sci. 47:546.

McMeekan, C. P. 1940. Growth and development in pig with special reference to carcass quality characters. III. Effect of plane of nutrition on form and composition of bacon pig. J. Agr. Sci. 30:511.

Messinger, W. J. and J. M. Steele. 1949. Relationships of body specific gravity to body fat and water content. Proc. Soc. Exp. Biol. Med. 70:316. 
Mitchell, H. H. and J. S. Hamilton. 1929. Swine type studies. III. The energy and protein requirements of growing swine and the utilization of feed energy in growth. Ill. Agr. Sta. Bul. 323.

Morales, M. F., E. N. Rathbun, R. E. Smith and N. Pace. 1945. Studies on body composition. II. Theoretical considerations tregarding the major body tissue components with suggestion for application to men, J. Biol. Chem. 158:677.

Moulton, C. R. 1923. Age and chemical development of mammals. J. Biol. Chem. 57:79.

Moulton, C. R., P. J. Trowbridge and L. D. Haigh. 1922. Studies in Animal Nutrition. III. Changes in chemical composition on different plans of nutrition. Mo. Agr. Exp. Sta. Res. Bul. 55.

Osinska, Zofia. 1962. Estimation of protein, chemical fat, and energy content in pigs. An. Prod. 4: Part III.

Reid, J. T., G. H. Wellington and H. O. Dunn. 1955. Some relationships among the major chemical components of the bovine body and their application to nutritional investigations. J. Dairy Sci. 38:1344.

Scott, E. L. 1930. Influence of the growth and fattening processes on the quantity and quality of meat yielded by swine. Ind. Agr. Exp. Sta. Res. Bul. 340 .

Spray, C. M. and E. M. Widdowson. 1951. The effect of growth and development on the composition of mammals. British J. Nutr. $4: 332$.

Wallace, H. D. 1965. Dietary protein level, feed restriction and sex influences on feed lot performance and carcass characteristics of finishing swine. Feedstuffs 37:18. 